\title{
THE HARMONIZING OF FAMILY LIFE AND WORK IN THE CONTEXT OF TYPOLOGY OF THE WELFARE STATE
}

\author{
Eva Rievajová, Zuzana Poláčiková
}

\section{Key words:}

the harmonizing of family and work life, welfare state, liberal type, conservative-corporatist type, social democratic type, employment of women, gender equality

\section{Kl’účové slová:}

zosúladenie rodinného a pracovného života, sociálny štát, liberálny typ, konzervatívnokorporatistický typ, sociálno-demokratický typ, zamestnanost' žien, rodová rovnost'

\begin{abstract}
:
This paper deals with theoretical approaches to the harmonization of family life and work based on the Esping-Andersen's typology of the welfare state. In the first chapter we characterize three basic types of the welfare state: liberal, conservative-corporatist and social democratic. We focus on the essential features, on the relationship between the state and the market, the level of stratification and decommodification in these different types. In the second chapter we analyze familiarization of the welfare state typology, refering to the criticism, which calls into questioning the ability of commodification by which Orloff underestimates this ability for some members of the society; we discuss approaches to social welfare, to the issues of decommodification and defamiliarization; we stress the term "women friendly" as one of the fundamental basis for the problem of reconciliation of work and family life. Systems of the social states vary widely in how they support parents in their efforts to balance work and family care, integration of mothers into the labor market, which subsequently affects the birth rate and the aging of the population.
\end{abstract}

\begin{abstract}
Abstrakt:
Príspevok sa zaoberá teoretickými prístupmi k harmonizácii rodinného a pracovného života vychádzajúc z typológie sociálneho štátu podl'a Esping-Andersena. V prvej kapitole charakterizujeme tri základné typy sociálneho štátu: liberálny, konzervatívno-korporatistický a sociálno-demokratický. Zameriavame sa na ich základné črty, na vzt’ah štátu a trhu, na stupeň stratifikácie a dekomodifikácie v jednotlivých typoch. V druhej kapitole analyzujeme familiarizáciu typológie sociálneho štátu, poukazujeme na kritiku, ktorou Orloff spochybňuje schopnost' komodifikovat' sa u niektorých členov spoločnosti, rozoberáme prístupy k sociálnej starostlivosti, k otázkam dekomodifikácie a defamiliarizácie, poukazujeme na prístup „priatel'ský voči ženám“ ako k jednému zo základných východísk k otázke zosúlad'ovania rodinného a pracovného života. Systémy sociálnych štátov sa vo vel'kej miere líšia v tom, akým spôsobom podporujú rodičov v ich úsilí o rovnováhu medzi zamestnaním a starostlivost'ou o rodinu, integráciu matiek na trh práce, čo má následne vplyv na mieru pôrodnosti a starnutie populácie.
\end{abstract}

\section{Introduction}

Since the nineteen sixties no country in Europe has been able to escape what is called the "dual phenomenon" - a falling birth rate and increasing female participation in the labor market. The number of women being educated on all levels rapidly increased with regards to the women born after the Second World War. This generation of women demonstrated a desire for economic independence. On this basis, employment has become a central 
component of their social identity. Subsequently, due to the global expansion of the control of reproduction, women in all European countries along with their partners can now decide on the issues of family planning. ${ }^{1}$ However, couples do not always have as many children as they would like to have. As a result of persistent in balances between the sexes in matters of the family, it is the women who are forced to make the decisions between motherhood and professional ambitions ${ }^{2}$. This dilemma is aggravated by the fact that mothers are confronted with these decisions at precisely the moment when they must invest in building their professional lives to secure their employment or career advancement. Therefore, since the nineteen sixties, along with the increasing age of first time mothers, we see that the period of decision making for family or career, is confronted with the period of giving birth and rising children. Thus in this context, the issue of harmonizing family, work and the support for working parents has become a leading social and political agenda. Family and family care is gradually becoming one of the domains of the overall state care - an important sector of public interest and accountability. The increasing interest in the family is enforced not only as a socio-political interest, but also as an interest in scientific research. ${ }^{3}$ The theme of social care has become a very important issue that is being stressed on state, market and family levels in many countries, including in relation to the paradox of our time - and family ethics. The harmonizing work and family life research is now one of the main discussions and investigations of social issues and is the object of social research. This paper is focused on the analysis of theoretical approaches to the reconciliation of work and family, based on the typology of the welfare state.

This paper is outcome within the project $\mathrm{OP} \mathrm{VaV}$ "Creating excellent workplace for economic research to address the civilization challenges in the 21 st century" (ITMS 26240120032): Supporting research in Slovakia. The project is co-financed by EU funds.

\section{Typology of the welfare state}

The variations on how family and work are combined in a multitude of countries are affected by social policy. Esping-Andersen described the first type of welfare state as liberal, as it focuses on the individual and assumes that everyone should be able to take care of the family through paid employment. The definition of liberalism is associated with the maximization of the free market with little or no state intervention in order to maintain a free market. The liberal theory assumes that all people are able to participate in the market. This leads to social stratification, because the basic premise is free competition which "produces winners and losers." Freedom to compete in the market may contain elements of uncertainty that may lead to poverty. From the liberal point of view "this is not a system error, but only a consequence

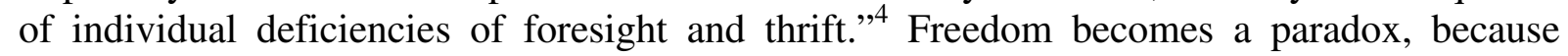
definition of freedom rarely includes images of poverty.

Historically, in terms of social policy, liberals believed that "minimal social wages will

\footnotetext{
${ }^{1}$ MCDONALD, P. 2005. Low fertility and the state. [online]. Princeton University, 2005. [2010.11.10.] $<$ http://paa2005.princeton.edu/download.aspx?submissionId=50133>.

${ }^{2}$ FINE-DAVIS, M. et al. 2004. Fathers and Mothers: Dilemmas of the Work-Life Balance: A Comparative Study in Four European Countries. [online]. Springer, 2004. [2010.11.10.] $<$ http://www.springer.com/social+sciences/book/978-1-4020-1848-0>.

${ }^{3}$ REPKOVÁ, K. 2007. Rodinná starostlivost' na Slovensku ako verejný záujem (Family care in Slovakia as a public interest). Bratislava: Inštitút pre výskum práce a rodiny, 2007. ISBN 978-80-7138-123-5. p. 7

${ }^{4}$ ESPING-ANDERSEN, G. 1990. The Three Worlds of Welfare Capitalism. Cambridge: Polity Press, 1990.

ISBN13: 978-0-691-02857-6. p.42
} 
eradicate poverty, but in fact they actively contribute to its perpetuation." ${ }^{, 5}$ It is also unlikely that such a worker will commodify himself completely in the market. Although liberals advocated financial bonds and were against intervention, which could disrupt the stratification produced in the market, representatives of liberalism also recognize "the dilemma of labor commodification" through minimal social policy. ${ }^{6}$

There are two main problems in the liberal welfare state. ${ }^{7}$ Firstly, the state eliminates a majority of the voters from receiving the social benefits, which is politically unpopular for social programs and unsustainable from a long term point of view (low services for poor and politically marginalized people). Secondly, it tends to create two-class society, according to the inadequate public services. The richer middle class is being provided with much better services in the market. The United States come the closest to the liberal social model when compared with any other Western welfare states, but it is not a perfect example. In the liberal welfare states (USA, Canada, Australia, Switzerland) the middle-class was not created by the state efforts. The historical dominance of liberalism was brought on due to the middle class's skepticism because of the stagnation of a strong state, which has stagnated for a long time with no response to requests from residents, while the middle class was so strong that it considered that the market would better satisfy their needs.

Governments in liberal welfare state types are generally stricter when it comes to funding for social programs, and social assistance is aimed at people without work or private sources. Social benefits are financed from taxes and set at a level which is lower than the minimum wage, while also providing incentives to seek employment. Liberal social regimes emphasize individual responsibility as opposed to collective responsibility. Based on its liberal roots, Britain developed a model in which the universal benefits and services significantly enhanced the fact that the state had a paternalistic concern for the health of its population and workforce. This model, named after Lord Beveridge, establishes general standards of care to which everyone is entitled.

The second type that Esping-Andersen identifies in countries such as Germany and Italy is conservative corporatist welfare state systems, considering that employers, unions and governments jointly provide social insurance and share the risk of loss of income due to unemployment, disability or illness. These systems are financed through employee and employer wage deductions (and sometimes enclosed with contributions from the state), benefits are usually generous for the contributor. Corporatist regimes are also conservative, because they are not designed to promote equality, but rather to secure labor income and contribute to social stability and cohesion for employers and the government.

Historical beginnings of a conservative approach to social policy, social welfare and decommodification of work are based on the stratification of class lines and the containment of a hierarchical society. Esping-Andersen distinguishes three ways that the conservative approach addresses commodification. Firstly, the model of feudal society is transferred to the business world, traditionally based on the ownership of the land progressing into the modern world; where it is updated attuned to the patriarchal state. Secondly, corporate social origins

\footnotetext{
${ }^{5}$ ESPING-ANDERSEN, G. 1990. The Three Worlds of Welfare Capitalism. Cambridge: Polity Press, 1990. ISBN13: 978-0-691-02857-6. p. 35-36

${ }^{6}$ ESPING-ANDERSEN, G. 1990. The Three Worlds of Welfare Capitalism. Cambridge: Polity Press, 1990. ISBN13: 978-0-691-02857-6. p. 42

${ }^{7}$ ESPING-ANDERSEN, G. 1999. Social Foundations of Postindustrial Economies. Oxford: Oxford University Press, 1999.
} 
in the Catholic Church, that are based on protection and assistance as a reward for loyalty to the church. Finally, statist conservatism arose in connection with the concept of fatherauthoritarian, that sees to the obligations of the ruling class and emphasizes individualism and protection of society as a whole. ${ }^{8}$ Overall, these elements of conservatism advocated minimum decommodification of work.

The state intervention to a large extent can be considered only as minimal in allocation of the fixed promotion of social stratification in society and maintaining hierarchical/patriarchal structures. For example, Germany belongs to the conservative model of welfare under the system introduced by Bismarck in 1890 and now introduces the policies formulated by political parties with the traditional Catholic and Lutheran base.

Child care is an area that has been overlooked by the Esping-Andersen typology in his study of the welfare state, especially given the fact that the Conservative government operates a third of all day-care centers and the rest is managed by the church, the prevailing reminiscence of preserving traditional patriarchal welfare. Governments of conservative welfare states remain on the sidelines when it comes to intervening, but unlike the individualistic liberal theory, it provides protection for those who are unable to succeed in the market. Esping-Andersen bases his theories on understanding family and child care according to the German example. Because children can not compete or participate in the market in this sense they can not be seen as a part of society. On one hand his claim might be correct, because this is a blind spot (children truly are not included in the study of commodified labor), on the other hand the preceding critique emphasizes the concept of protecting those who can not be categorized as commodified workers. Held in comparison to the liberal state, such as the United States, where child care is a largely profitable business and commodified workers pay for the care of those who are not able to enter the market.

In social-democratic welfare states such as Sweden or Denmark, use taxes for the redistribution of income to maintain full employment and thus avoiding poverty. The socialdemocratic approach to welfare and social policy secures the reduction of social differences; promotes the theory of full employment; and promotes equality, including the insurance that guarantees a network in which nobody should seep through. As with liberalism, social democracy, welfare advocates individualism and seeks to eliminate dependence on family as the first alternative on the market. The main concern is not to wait until the family is unable to provide further assistance, but to "set up prevention of the family costs." conflict with the conservative approach, which assumes that the family is a constant variable. The priority is to bring about vicissitude in the decommodified workers by way of universal and comprehensive social policy. The basic belief is that "all the benefits are limited, and everyone will most likely feel obliged to pay for the benefits." 10 The reality of fully socialized social programs is minimal, due to extensive cost of maintenance and the problems faced by governments, trying to convince people to pay higher taxes to ensure those who are not able compete in the market, either voluntarily or involuntarily. However, there are several countries that seek a high level of de-commodification. The best examples are found in Scandinavia. In 1980, Esping-Andersen calculated the levels of de-commodification in the

\footnotetext{
${ }^{8}$ ESPING-ANDERSEN, G. 1990. The Three Worlds of Welfare Capitalism. Cambridge: Polity Press, 1990. ISBN13: 978-0-691-02857-6. p. 38-41

${ }^{9}$ ESPING-ANDERSEN, G. 1990. The Three Worlds of Welfare Capitalism. Cambridge: Polity Press, 1990. ISBN13: 978-0-691-02857-6.

${ }^{10}$ ESPING-ANDERSEN, G. 1990. The Three Worlds of Welfare Capitalism. Cambridge: Polity Press, 1990. ISBN13: 978-0-691-02857-6.
} 
market in eighteen countries. Calculations were based on the amount of benefits received and the amount of contributions. As expected, data from Norway and Sweden showed an eminent level of de-commodification. Within these analyses The United States and Australia are rated among the states with the lowest degree of de-commodification, in accordance with liberal regimes in these countries.

The Scandinavian welfare state is also characterized by its extensive focus on services (day care, elderly care, home help, etc.). Claims are generally the same, but the system is tailored to the differentiated expectations (eg, benefits are scaled to income). Because the level of public services is so advanced that the state de facto expelled all private actions in competition. Scandinavian welfare state tends to reduce class differences and income disparities, while ensuring the highest possible level of services. Critics pointed to the huge costs that lead to a very high tax burden. Although studies have shown that social-democratic welfare states (Sweden, Denmark, Norway) are less prone to job loss in sectors requiring low skills (low-skill sector) as a conservative model, since the social-democratic model is less dependent on payroll taxes.

Differences between social regimes by Esping-Andersen depend on factors such as the philosophy of the ruling party or coalition of powerful interest groups and political parties.

\section{The familiarization typology of welfare state}

The typology of three welfare regimes was often criticized and commented on in the last fifteen years, and this is because it is focused mainly on the north-western Europe. The Mediterranean model, which is applied in Greece, Spain, Italy, Portugal and Cyprus, and is characterized by limited state intervention with respect to the strong Christian and family traditions in the area of responsibility and care of the family; this model was separated later. The fifth type of regime - the post-communist regime, which combines elements of all four models, was introduced after European Union grew in size. ${ }^{11}$

As a consequence of the falling birth rates and along with the harmonization of work and family life, the population is aging. The current issue of the aging population brings up the question of the sustainability of pension systems. According to OECD analysis ${ }^{12}$ in 1950, it took more than seven people in the economically active age to ensure one pensioner. This proportion dropped to six in 1963, then to five in 1976, and currently this ratio is at four. It is anticipated that over the next 40 years, this ratio will be reduced from 3:1 in 2023 and 2:1 in 2047. The largest decrease is predicted in the years 2015-2035, when the generation born during the period of increased birth rate will reach retirement age. It is important to realize that any efforts only slow the problem down; therefore it is necessary to address the causes of the problem. To tackle the effects of population aging by means of reforms of pension systems can be effective only when designed to address the causes of this problem - falling birth rates - through the support for families and also through the harmonization of work and family. ${ }^{13}$

\footnotetext{
11 BLOSSFELD, H.P., DROBNIČ, S. 2001. Careers of couples in contemporary society. Oxford: Oxford University Press 2001.

${ }^{12}$ OECD. 2009. Pensions at a Glance 2009. OECD Publishing: 2009. ISBN 978-92-64-06071-5.

${ }^{13}$ RIEVAJOVÁ, E. - POLÁČIKOVÁ, Z. K vybraným otázkam dôchodkových reforiem v krajinách OECD (On the issue of pension reforms in OECD countries). In Nová ekonomika : vedecký časopis Národohospodárskej
} 
Ann S. Orloff ${ }^{14}$ notes that, in order for a working family member to become de-comodified they first must be commodified. Unpaid care performed by women in the households is not eligible for commodification, and therefore, also not entitled for de-commodification. There have been proposed various methods of distribution between paid and unpaid work in the family; known as a "breadwinner" and "two incomes", and each one of them is representing a different model. After examining these two models, we come to the conclusion that the possibility of how to distribute paid and unpaid work in households with two incomes is meant as the highest degree of equality among women and men. ${ }^{15}$

Work is a source of activity, allowing people to acquire certain knowledge and skills that are necessary for the job. Work creates a regime - the structure of the day is shaped according to the work activity, and the non-working time is its counterpart. Work is a source of personal identity that provides a strong sense of social identity, which is very important, especially for man. This is self-esteem associated with their economic benefits to the households. Thru work people not only satisfy their basic biological needs, but also their needs for socially - selfrealization, social relations, recognition by others, etc.. Human work represents an important social value.

Unlike the bias against female, Esping-Andersen's view of the typology could also be diagnosed as an impact of "Swedocentric", which indicates that Sweden and Scandinavian standards are commonly being used to measure and evaluate all other types of welfare states. These two arguments should not exclude each other in this particular case, taking into account the fact that the Scandinavian regime's concept of a family with two incomes, where care for children and elderly is more likely provided by the State.

In response to this criticism, Esping-Andersen introduced the concept of "de-familiarisation". In accordance with the concept of de-commodification, this term talks about the extent to which household welfare and caring responsibilities have relaxed - either via welfare state provision or through market measures. ${ }^{16}$ The availability of childcare and care for elderly people are in this sense to be regarded as factors that facilitate the de-familiarisation.

Orloff $^{17}$ criticisms this classification of social arrangements and comes up with a new typology. She addresses some general considerations concerning the balance between work and family life. Social policies that promote reconciliation of work and family life as a means of solving the problems of falling birth rates and inequality between women and men, are part of the agendas in many European countries. Just a few decades ago, the idea of reconciling work and family life was exclusively a female matter. While this generally becomes "a

fakulty Ekonomickej univerzity v Bratislave. - Bratislava : EKONÓM, 2010. ISSN 1336-1732, December 2010, roč. 3, č. 4, s. 25-33. ITMS 26240120032.

${ }^{14}$ ORLOFF, A. 1993. Gender and the social rights of citizenship: state policies and gender relation in comparative perspective. In American Sociological Review, vol 58, no 3.

${ }^{15}$ LEWIS, J. 1992. Gender and the Development of Welfare Regimes, In Journal of European Social Policy, 1992, vol 2, no 3, p. 159-173.

${ }^{16}$ ESPING-ANDERSEN, G. 1999. Social Foundations of Postindustrial Economies. Oxford: Oxford University Press, 1999. p. 51

${ }^{17}$ ORLOFF, A. 2005. Social Provision and Regulation: Theories of States, Social Policies, and Modernity. In: J. Adams - E. S. Clemens -A. S. Orloff (eds.): Remaking Modernity: Politics, History, and Sociology, Durham, N.C.: $190-224$ 
woman's dilemma"; it is about compromise between employment and motherhood. ${ }^{18}$ The right (and obligation) of fathers in the care of family and participation in childcare has been reinforced and there has been introduced a new definition of masculinity and men. ${ }^{19}$

The trends of female employment vary considerably in developed Western countries; Scandinavia and the USA are countries with high participation of women in the work force compared to southern European countries (except Portugal). ${ }^{20}$ In addition, research data shows that although women's labor participation rates in the market are different, models of division of labor in the home and family are almost similar. ${ }^{21}$ Although the involvement of men in childcare and unpaid domestic labor is slightly increased in some countries; it is a "drop in the ocean in relation to losses in relation to mothers working full time." 22 This means that in all countries women have experienced double load: paid work in the labor market and unpaid household work.

"Women friendly" as a term in welfare states is a key element in the debate on reconciling work and family life. It was introduced by Norwegian political scientist Helga M. Hernes in 1987. ${ }^{23}$ Hernes defined "women friendly" as "an environment that would not be harder against the choices of women as to men, or would not permit unfair treatment based on sex." The term "women friendly" was then applied to the Scandinavian welfare states, which have the potential for this idea, given the already relatively high degree of equality between women and men.

Looking at the different interpretations of what should be understood by "woman friendly"; there may be differences in the similarities. All seem to agree that the responsibility for housework and family care should be provided to women, but it raises the fundamental question of what or who should take over? Some theories emphasize the role of the state and public institutions, while others also emphasize the responsibility of men. According to Esping-Andersen ${ }^{24}$, content of "women-friendly" policies could be summarized as follows: 1) as acceptable and accountable in the day care, 2) open to a paid maternity and parental leave, and 3) accepting absence when children are sick. Daly ${ }^{25}$ also points out that child care, parental leave and benefits are crucial to women's participation in the labor market. The inclusion of parental leave to these factors intends to engage fathers in childcare, and thus pursues even more distribution of family responsibilities.

\footnotetext{
${ }^{18}$ ESPING-ANDERSEN, G. 2002. A child centred social investment strategy. In: G.Esping-Andersen, D. Gallie, A. Hemerijcks and J. Myles (eds) Why we Need New Welfare State. Oxford: Oxford University Press, 2002.

${ }^{19}$ LEIRA, A. 2002. Working parents and the welfare state. Cambridge: Cambridge University Press, 2002.

${ }^{20}$ DALY, M. - LEWIS, J. 2000. The concept of social care and the analysis of contemporary welfare states. In British Journal of Sociology. [online]. 2000, vol. 51, no. 2. [2011.03.01.]. <http://ritsumeigssgp.jp/sansyagp/lecture/lecture-

pdf/Mao\%20Saito/100622_The\%20_Concept_of\%20_Social_Care_and_the\%20_Analysis_of\%20_Contemporar y_Welfare\%20_States.pdf>

${ }^{21}$ BOND, S. 2002. Family Friendly Working? Puting Policy into Practice. York: Joseph Rowntree Foundation, 2002.

${ }^{22}$ HOBSON, B. 2002. Making Men into Fathers. Cambridge: Cambridge University Press 2002.

${ }^{23}$ ORLOFF, A. 1993. Gender and the social rights of citizenship: state policies and gender relation in comparative perspective. In American Sociological Review. 1993, vol 58, no 3.

${ }^{24}$ ESPING-ANDERSEN, G. 2002. A child centred social investment strategy, in G.Esping-Andersen et al.: Why we Need New Welfare State. Oxford: Oxford University Press, 2002.

${ }^{25}$ DALY, M. - LEWIS, J. 2000. The concept of social care and the analysis of contemporary welfare states.

In British Journal of Sociology [online]. 2000, vol. 51, no. 2. [2011.03.01.]. <http://ritsumeigssgp.jp/sansyagp/lecture/lecture-

pdf/Mao\%20Saito/100622_The\%20_Concept_of\%20_Social_Care_and_the\%20_Analysis_of\%20_Contemporar y_Welfare\%20_States.pdf>
} 
Esping-Andersen's problem of "familiarisation" and how the concept of gender is conceived is that his analysis is biased against mothers. As Daly ${ }^{26}$ also said, women are particularly affected by the tasks associated with the family. The family in Esping-Andersen's theory looks at women as "citizens"; but in its original analysis of 1990, they are representing the sign of man. In his book Social foundations of Post-Industrial Economy in 1999, he came to the conclusion that to face the problem of the low employment rate of women, the solution to redistribute the family care responsibilities to the state, not the redistribution of responsibility between the mother and the father. Although he permitted that this could be the right choice with regard to gender equality, it would ensure optimal (win-win) situation for both parents. ${ }^{27}$

Orloff defines as follows: "The state is open to women, while ensuring the division of labor between the genders that shifted the burden of family care services and public men." 28 This underlines that the men should be part of home care and upbringing of children.

An important link is just mentioned about concept of care. For a very long period of time the care has been attributed to women. The concept of care says that since the beginnings of life care characterizes the status of women. The nature of the work involved in care was focused on an activity that is caring for others. By identifying the specific nature of care and its unique properties as well as responsibility for it, the status of women is being empowered. Care represents in relation to the family unpaid work and domestic passenger services through the social relations of marriage and kinship. The concept of care turned the attention to the economic importance of care, and this activity is understood as an activity of (mostly unpaid) caregivers. $^{29}$

Welfare states systems differ in how they support parents in their efforts to balance work and family life, but they also differ in the extent to which promoting equality between women and men in family care is an issue. Leave for family reasons - social policy can give parents the time to care for young children under the rules governing working time. Social policy can support the provision of care throughout the life cycle of the child. Maternity and paternity leave may be taken by both parents but men prefer better-paid jobs, while childcare is being provided with the support of policies to make it available and affordable in high-quality alternative to maternity care, enhancing the employability of women. ${ }^{30}$ These are only isolated cases, and the question is raised here; whether alternative form of maternity care is

\footnotetext{
${ }^{26}$ DALY, M. - LEWIS, J. 2000. The concept of social care and the analysis of contemporary welfare states. In British Journal of Sociology [online]. 2000, vol. 51, no. 2. [2011.03.01.]. <http://ritsumeigssgp.jp/sansyagp/lecture/lecturepdf/Mao\%20Saito/100622_The\%20_Concept_of\%20_Social_Care_and_the\%20_Analysis_of\%20_Contemporar y_Welfare\%20_States.pdf>

${ }^{27}$ ESPING-ANDERSEN, G. 1999. Social Foundations of Postindustrial Economies. Oxford: Oxford University Press, 1999.

${ }^{28}$ ORLOFF, A. 1993. Gender and the social rights of citizenship: state policies and gender relation in comparative perspective. In American Sociological Review. 1993, vol 58, no 3.

${ }^{29}$ DALY, M. - LEWIS, J. 2000. The concept of social care and the analysis of contemporary welfare states. In British Journal of Sociology. [online]. 2000, vol. 51, no. 2. [2011.03.01.]. <http://ritsumeigssgp.jp/sansyagp/lecture/lecturepdf/Mao\%20Saito/100622_The\%20_Concept_of\%20_Social_Care_and_the\%20_Analysis_of\%20_Contemporar y_Welfare\%20_States.pdf $>$

${ }^{30}$ GORNICK, J.C. - MEYERS, M. 2003. Families that work: Policies for reconciling parenthood and employment. [online]. 2002. [2011.07.01.]. <

http://www.ssc.wisc.edu/ wright/Gornick_Meyers_Giele_final_chapter1.pdf>
} 
the appropriate way to educate children. In addition cash benefits to paid leave for family reasons helps families to be economically secured.

In general, system of social-democratic welfare states adopt policies that are mostly focused on the promotion and development of two earnings: two careers household model (dualearner/dual-career) - This is the model of society that appreciates paid work and providing parental care for the price of a good upbringing of the child. ${ }^{31}$

Conservative policy in the European countries is helping to ensure time for family care, but acts to a lesser extent in allowing or encouraging gender equality in paid and unpaid work. In those countries where there is inequality between the genders (gender-inegalitarianism), division of labor remains the most unbalanced.

In liberal countries, state policies aimed at supporting employed parents are minimal. In these countries, the majority of parents would be "at the mercy" of their employers, for example, paid leave to care for the family and, flexible work and leisure. Most parents try to provide family care by the private markets as well as to provide care in educational establishments, especially during the first five years of childrens' life. Experience shows that when states act in insufficiently to provide assistance to parents with the costs of raising children, they are not distributed through the labor and consumer markets, parents and children suffer on average to the same extent as it is neglected gender equality. ${ }^{32}$

Parents throughout Europe and the United States share a common problem of balancing the responsibilities between their jobs and homes. Mothers and fathers everywhere are struggling with dividing time between work and home. Despite the relatively same problems the welfare states and social policies applied, the different labor markets differ in the level of support provided to parents and the equality between women and men in terms of dividing the time between the employment and family care. Parents in some countries, particularly in northern Europe and lesser throughout the whole European continent, benefit from parental leave. Social policies that provide them with paid leave to care for their young children regulate the labor market e.g. shortening of working time during children's childhood and public programs that guarantee access to high-quality care of their children at the time their parents spend at work. ${ }^{33}$

In some countries the public regulations to parents not only support their families but also support equality between women and men through the consolidation of the mother's position in the labor market and/or encouraging fathers to spend more time providing children care. Public funding of these programs divides the cost of raising children in general, while the financial burden is shared among all the types of families, generations and the private sector. ${ }^{34}$ In other countries, most notably in the U.S., where the view of child education is strictly taken

\footnotetext{
${ }^{31}$ GORNICK, J.C. - MEYERS, M. 2003. Families that work: Policies for reconciling parenthood and employment. [online]. 2002. [2011.07.01.]. < http://www.ssc.wisc.edu/ wright/Gornick_Meyers_Giele_final_chapter1.pdf>

${ }^{32}$ GORNICK, J.C. - MEYERS, M. 2003. Families that work: Policies for reconciling parenthood and employment. [online]. 2002. [2011.07.01.]. < http://www.ssc.wisc.edu/ wright/Gornick_Meyers_Giele_final_chapter1.pdf>

${ }^{33}$ GORNICK, J.C. - MEYERS, M. 2003. Families that work: Policies for reconciling parenthood and employment. [online]. 2002. [2011.07.01.]. < http://www.ssc.wisc.edu/ wright/Gornick_Meyers_Giele_final_chapter1.pdf>

${ }^{34}$ RIEVAJOVÁ, E et al. Sociálne zabezpečenie (Social security). Bratislava : Vydavatel'stvo EKONÓM, 2011. 291 s. ISBN 978-80-225-3190-0.
} 
from the private point of view, parents are largely responsible themselves to solve the problem of harmonizing work and family. In the U.S. parents obviously rely on their employers to provide them paid leave for family reasons and the possibility of flexible work time while providing of care for children using the market services.

\section{Conclusion}

Social policy dealing with the integration of mothers in the labor market varies considerably worldwide. Despite the institutional and political background, it is apparent that countries with high participation of mothers in the labor force and relatively high birth rates are those who advocate and promote appropriate employment for mothers; they apply a gendersensitive policy. On the other hand, the countries with low birth rates and low participation of mothers in the labor market, e.g. Spain and Italy, are countries where women face more obstacles when they want to work full time. ${ }^{35}$

While general trends are similar, there are significant differences between countries concerning the participation of women in the labor market and declining birth rates. These differences are in spite of the fact that in each country the political objectives of reconciling work and family have moved significantly forward, and the harmony of these changes is different. Second, each country has different welfare regime with a different importance of harmonizing work and family policy, which is based on the ranking values of individuals, families and employers. Thirdly, the participation of mothers in the workforce and access to mothers at work is different in varies countries, but there can be found also many similarities.

All the European countries due to convergence of social and economic conditions in the communities have to solve problems that are similar. National governments deal with the socio-economic problems which include reducing the government deficit of reformed pension systems, reducing unemployment, fighting poverty and social exclusion, reconciling work and family life and many others. In the new conditions concerning the globalization process and fading financial and economic crisis, many countries have to find compromises and make unpopular decisions.

\section{Summary}

The contribution of this article is focused on theoretical approaches to issues of harmonization of work and family life based on the typology of the welfare state. They are characterized by three basic types of welfare states, their basic features, access to social care and the issue of reconciliation of work and family life. The systems of welfare states differ in level of parents support in their effort to balance employment and family care and integration of mothers in the labor market. It refers to the relationship between birth rate and aging of population.

\section{References:}

[1] BLOSSFELD, H.P., DROBNIČ, S. Careers of couples in contemporary society. Oxford: Oxford University Press, 2001.

[2] BOND, S. Family Friendly Working? Puting Policy into Practice. York: Joseph Rowntree Foundation, 2002.

\footnotetext{
${ }^{35}$ CASTLES, F. G. 2003. The World Turned Upside Down: Below Replacement Fertility, Changing Preferences and Family-Friendly Public Policy in 21 OECD Countries. In Journal of European Social Policy [online]. 2003, vol. 13, no. 3 [2011.05.01.]. <http://esp.sagepub.com/content/13/3.toc>
} 
[3] CASTLES, F. G. The World Turned Upside Down: Below Replacement Fertility, Changing Preferences and Family-Friendly Public Policy in 21 OECD Countries. In: Journal of European Social Policy [online]. 2003, vol. 13, no. 3 [2011.05.01.]. Source: $<$ http://esp.sagepub.com/content/13/3.toc >

[4] DALY, M. - LEWIS, J. The concept of social care and the analysis of contemporary welfare states. In: British Journal of Sociology. [online]. 2000, vol. 51, no. 2. [2011.03.01.].Source<http://ritsumei-gssgp.jp/sansyagp/lecture/lecture-

pdf/Mao\%20Saito/100622_The\%20_Concept_of\%20_Social_Care_and_the\%20_Analy sis_of\%20_Contemporary_Welfare\%20_States.pdf $>$ ]

[5] ESPING-ANDERSEN, G. The Three Worlds of Welfare Capitalism. Cambridge: Polity Press, 1990. ISBN13: 978-0-691-02857-6.

[6] ESPING-ANDERSEN, G. Social Foundations of Postindustrial Economies. Oxford: Oxford University Press, 1999.

[7] ESPING-ANDERSEN, G. A child centred social investment strategy. In: G.EspingAndersen, D. Gallie, A. Hemerijcks and J. Myles (eds) Why we Need New Welfare State. Oxford: Oxford University Press, 2002.

[8] FINE-DAVIS, M. et al. Fathers and Mothers: Dilemmas of the Work-Life Balance: A Comparative Study in Four European Countries. [online]. Springer, 2004. [2010.11.10.]. Source: <http://www.springer.com/social+sciences/book/978-1-40201848-0>.

[9] GORNICK, J.C. - MEYERS, M. Families that work: Policies for reconciling parenthood and employment. [online]. 2002. [2011.07.01.]. Source: < http://www.ssc.wisc.edu/ wright/Gornick_Meyers_Giele_final_chapter1.pdf>.

[10] HOBSON, B. Making Men into Fathers. Cambridge: Cambridge University Press, 2002.

[11] LEIRA, A. Working parents and the welfare state. Cambridge: Cambridge University Press, 2002.

[12] LEWIS, J. Gender and the Development of Welfare Regimes, In Journal of European Social Policy, 1992, vol 2, no 3, p. 159-173.

[13] MCDONALD, P. Low fertility and the state. [online]. Princeton University, 2005. [2010.11.10.]Source:<http://paa2005.princeton.edu/download.aspx?submissionId=5013 $3>$.

[14] OECD. Pensions at a Glance 2009. OECD Publishing: 2009. ISBN 978-92-64-06071-5.

[15] ORLOFF, A. Gender and the social rights of citizenship: state policies and gender relation in comparative perspective. In: American Sociological Review, vol 58, no 3.

[16] ORLOFF, A. Social Provision and Regulation: Theories of States, Social Policies, and Modernity. In: J. Adams - E. S. Clemens -A. S. Orloff (eds.): Remaking Modernity: Politics, History, and Sociology, Durham, N.C. 2005.

[17] POLÁČIKOVÁ, Z. Politiky podporujúce rodičovstvo v EÚ (Policies supporting parenthood in EU). In: Východiská a výzvy pre sociálnu politiku v nastávajúcom desat'roči : elektronický zborník príspevkov z medzinárodnej vedeckej konferencie: Bratislava 9. jún 2011. S. [1-6]. - Bratislava: [Katedra sociálneho rozvoja a práce NHF EU], 2011. ISBN 978-80-225-3208-2.

[18] REPKOVÁ, K. Rodinná starostlivost' na Slovensku ako verejný záujem (Family care in Slovakia as a public interest). Bratislava: Inštitút pre výskum práce a rodiny, 2007. ISBN 978-80-7138-123-5.

[19] RIEVAJOVÁ, E. - POLÁČIKOVÁ, Z. K vybraným otázkam dôchodkových reforiem v krajinách OECD (On the issue of pension reforms in OECD countries). In: Nová ekonomika : vedecký časopis Národohospodárskej fakulty Ekonomickej univerzity v 
Bratislave. Bratislava : EKONÓM, 2010. ISSN 1336-1732, December 2010, roč. 3, č. 4, s. 25-33. ITMS 26240120032.

[20] RIEVAJOVÁ, E. et al. Sociálne zabezpečenie (Social security). Bratislava: Vydavatel'stvo EKONÓM, 2011. 291 s. ISBN 978-80-225-3190-0.

JEL Classification: J11, J13

prof. Ing. Eva Rievajová, Ph.D.

Katedra sociálneho rozvoja a práce

Národohospodárska fakulta

Ekonomická univerzita Bratislava

Dolnozemská cesta 1, 85235 Bratislava

eva.rievajova@euba.sk

Ing. Zuzana Poláčiková

Katedra sociálneho rozvoja a práce

Národohospodárska fakulta

Ekonomická univerzita Bratislava

Dolnozemská cesta 1, 85235 Bratislava

susy_polacikova@yahoo.com 